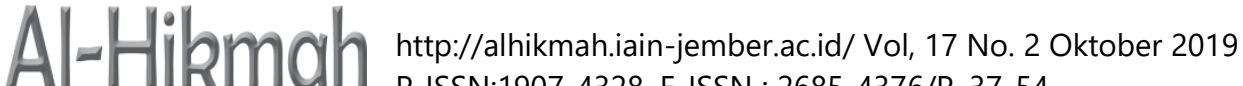 P-ISSN:1907-4328, E-ISSN : 2685-4376/P. 37-54
}

\section{Komodifikasi Agama pada Perumahan Syariah di Surabaya}

\author{
Yelly Elanda \\ Universitas Wijaya Kusuma Surabaya \\ yelly.elanda@gmail.com
}

\begin{abstract}
Syariah housing has now penetrated the city of Surabaya. The syariahisation project is a form of the commodification of religion that marries business and religious symbols. The rise of syariah housing will result in spatial and social segregation. This paper will discuss the forms of the commodification of religion in syariah housing and the impact of the commodification of religion in syariah housing in the Surabaya area. This research uses descriptive qualitative method. Data collection techniques through literature studies by collecting all material or data that corroborate and are related to the study of sharia housing and the commodification of religion. The results of this study indicate that there are four forms of the commodification of religion in syariah housing. First, from the facilities offered by the use of religious labels in the form of an Islamic environment, there are regular studies, tahfidz houses, mosques, archery areas. Second, the marketing strategy by using a tagline that contains elements of Islam; inviting customers to the concept of religious seminars, using the names of housing that is closely attached to the nuances of Islam. Third, "Islamic" fashion used by marketing agents and models in the brochure. Fourth, syariah-based payment systems. With the concept of sharia housing this will have an impact on the formation of social identity and creating a gated community.

Keywords: Syariah Housing, Commodification of Religion, Social Identity, Gated Community
\end{abstract}

\section{Abstrak}

Perumahan syariah kini sudah merambah kota Surabaya. Proyek syariahisasi merupakan bentuk komodifikasi agama yang mengawinkan bisnis dan simbol-simbol agama. Maraknya perumahan syariah akan mengakibatkan segregasi spasial dan sosial. Tulisan ini akan membahas tentang bentuk-bentuk komodifikasi agama di perumahan syariah dan dampak dari komodifikasi agama di perumahan syariah di wilayah Surabaya. Penelitian ini menggunakan metode deskriptif kualitatif. Teknik pengumpulan data melalui studi kepustakaan dengan mengumpulkan semua bahan atau data yang menguatkan dan berkaitan dengan kajian perumahan syariah dan komodifikasi agama. Hasil penelitian ini menunjukkan bahwa ada empat bentuk komodifikasi agama di perumahan syariah. Pertama, dari fasilitas yang ditawarkan dengan penggunaan label keagamaan berupa lingkungan islami, ada pengajian rutin, rumah tahfidz, masjid, tempat panahan. Kedua, strategi pemasaran dengan menggunakan tagline yang mengandung unsur Islam; mengundang pelanggan dengan konsep seminar religi, menggunakan nama-nama perumahan yang lekat 
dengan nuansa Islam. Ketiga, busana "Islami" yang digunakan oleh para agen pemasaran dan model-model dalam brosur. Keempat, sistem pembayaran berbasis syariah. Dengan konsep perumahan syariah ini akan berdampak pada terbentuknya identitas sosial dan terciptanya gated community.

Kata kunci: Perumahan Syariah, Komodifikasi Agama, Identitas Sosial, Gated Community

\section{Pendahuluan}

Dalam perkembangannya kota terus meluas, tidak lagi fokus pada pusat kota. Kawasan pusat kota kini diduduki oleh berbagai macam perusahaan multinasional, pusat pemerintahan dan kawasan elit yang telah membentuk ekslusivisme sosial. Perebutan, invasi dan pengubahan tata ruang kota bisa terlihat dalam pengembangan komunitas sosial yang ada di wilayah perkotaan. Zona-zona perkotaan ini merupakan arena terbatas yang menunjukkan identitas penghuninya, sebagaimana yang dinyatakan oleh Burgess bahwa berbagai kelompok sosial dialokasikan ke dalam zona. Konstruksi "tipe ideal" kota yang dikemukakan oleh Burgess semakin meluas dari Distrik Pusat Bisnis (Central Business District/CBD). Keluar dari kawasan pusat bisnis zona terdapat beberapa zona yang akan dilewati, diantaranya adalah: (1) zona transisi; (2) lingkungan perumahan kelas pekerja; (3) zona hunian kelas atas; (4) lingkungan para komuter di kota-kota satelit. ${ }^{1}$ Dari pemaparan tersebut, dapat terlihat bahwa masing-masing zona dimiliki oleh komunitas yang dibentuk berdasarkan jumlah pendapatannya. Ruang menjadi faktor yang dominan dalam membentuk ekonomi dan kebudayaan sebab tempat tinggal akan mempengaruhi bagaimana cara hidup seseorang.

Hasil penelitian di banyak tempat di Asia pada penghujung abad ke 20 menunjukkan bahwa kebangkitan kaum kaya baru di Asia adalah kebangkitan kelas menengah perkotaan di kalangan umat muslim (Chua 2000; Embong 2002; Pinches 1999; Prasetyantoko 1999; Robinson dan Goodman 1995; Tanter dan Young 1990). ${ }^{2}$ Terbentuknya golongan kaya baru yang diisi oleh kalangan muslim, membuat kapitalis harus bersekutu dengan agama untuk memperluas pangsa pasar. Sebagaimana dinyatakan oleh Rudnyckyj, ternyata agama dan kapitalisme bukan hanya dapat hidup berdampingan dan memiliki keterkaitan, keduanya bahkan dalam beberapa kasus bisa bersekutu hingga mampu mendukung kegiatan-kegiatan kolektif yang berjangka panjang. ${ }^{3}$ Perkawinan antara bisnis dan simbol keagamaan ini disebut dengan komodifikasi agama karena menggunakan simbol agama untuk memasarkan produknya termasuk property. Perumahan syariah kini telah merambah di Surabaya.

\footnotetext{
${ }^{1}$ Chris Barker, Cultural Studies (Yogyakarta: Kreasi Wacana, 2013), 315

${ }^{2}$ Ariel Heryanto, Identitas dan Kenikmatan (Jakarta: PT Gramedia, 2015), 51

${ }^{3}$ Daromir Rudnyckyj, Spiritual Economies: Islam and Neoliberalism in Contemporary Indonesia, (Cultural Anthropology, 2009)
} 
Kota Surabaya adalah kota metropolis kedua setelah Jakarta dimana Surabaya menjadi kota rujukan bagi masyarakat untuk melakukan urbanisasi. ${ }^{4}$ Surabaya sebagai ibu kota Jawa Timur memiliki daya tarik bagi masyarakat daerah untuk datang dan bahkan menetap di Surabaya. Surabaya sebagai pusat pemerintahan, kota pendidikan, pusat pelayanan kesehatan dan kota industri menjadikan Surabaya sebagai tempat untuk mencari lapangan kerja. Banyak masyarakat yang datang dari luar daerah untuk mengadu nasib ke Surabaya. Setiap tahun penduduk daerah terus berdatangan ke Surabaya. Berikut adalah jumlah penduduk pendatang dari tahun ke tahun:

\section{Tabel 1.}

Jumlah Penduduk Datang

\begin{tabular}{ccccccc}
\hline Tahun & $\mathbf{2 0 0 9}$ & $\mathbf{2 0 1 0}$ & $\mathbf{2 0 1 1}$ & $\mathbf{2 0 1 2}$ & $\mathbf{2 0 1 3}$ & $\mathbf{2 0 1 4}$ \\
\hline $\begin{array}{c}\text { Jumlah Penduduk } \\
\text { Pendatang }\end{array}$ & 50.995 & 61.649 & 41.441 & 111.594 & 65.048 & 67.416 \\
\hline
\end{tabular}

Sumber: Dinas Pendaftaran Penduduk dan Pencatatan Sipil Kota Surabaya ${ }^{5}$

Semakin banyak penduduk yang datang ke kota maka secara tidak langsung turut mempengaruhi perkembangan sebuah kota. Kota akan terus mengalami pertumbuhan, perkembangan dan pemekaran dengan membentuk suatu model. Setiap model memiliki pola pertumbuhan kota yang berbeda-beda namun pada dasarnya setiap model memiliki zona. Zona ini akan terbagi sesuai dengan fungsi lahan (zona pemukiman, perdagangan, pusat kota, manufaktur) dan sesuai dengan klasifikasi ekonomi para penghuni (zona perumahan elite, kelas menengah, kelas pekerja, kelas pekerja terbawah, menengah ke bawah). ${ }^{6}$ Perkembangan dan pertumbuhan kota Surabaya semakin lama semakin menjauhi pusat kota dan berkembang menuju pinggiran kota. Zona yang dekat dengan pusat kota akan bernilai ekonomi tinggi dan menjadi kawasan perumahan elite, sedangkan kawasan pinggiran kota menjadi zona bagi kalangan kelas menengah ke bawah\&pekerja. Zona-zona ini telah men-

\footnotetext{
${ }^{4}$ Urbanisasi adalah perpindahan penduduk dari desa ke kota. Terdapat dua bentuk urbanisasi yakni migrasi dan mobilitas. Perbedaan diantara keduanya adalah jangka waktu yang diperlukan untuk tinggal. Migrasi diartikan sebagai perpindahan yang menetap dan mobilitas adalah perpindahan yang bersifat sementara (Damsar\&Indiriyani, Pengantar Sosiologi Perkotaan (Jakarta: Kencana,2017)), 133

${ }^{5}$ Banyaknya Penduduk Datang yang Dilaporkan Hasil Registrasi 2009-2014 (Surabaya: Badan Pusat Statistik Kota Surabaya, 17 April 2018) tersedia di https://surabayakota.bps.go.id/ statictable/2015/01/09/329/banyaknya-penduduk-datang-yang-dilaporkan-per-kecamatan-hasilregistrasi-2009---2014.html; Internet; diunduh pada 11 Oktober 2019

${ }^{6}$ Terdapat enam model tentang perkembangan dan pertumbuhan kota diantaranya adalah model poros, model konsektoral Amerika Latin, model konsektoral Eropa, model periferi, model nucleus majemuk, model sector, model zona konsentris (Damsar\&Indriyani, Pengantar Sosiologi Perkotaan, 148-152)
} 
imbulkan segregasi spasial berdasarkan pada tingkat perekonomian atau stratifikasi sosial.

Selain terjadi pembagian zona berdasarkan pada stratifikasi sosial, segregasi spasial juga berdasarkan pada diferensiasi sosial. Sejak zaman penjajahan, di Surabaya sudah terjadi pengelompokkan pemukiman berdasarkan pada ras dan etnis. Di kota Surabaya, terdapat zona pemukiman yang dihuni berdasarkan pada etnis yakni kampung Arab dan kampung pecinan yang dihuni oleh para keturunan Arab dan Cina yang telah lama tinggal di Surabaya. Zona pemukiman berdasarkan ras terdapat pemukiman Eropa meliputi Jalan Rajawali, Jembatan Merah, Kepanjen, Veteran, Branjangan, garuda, Penjara kemudian berkembang ke selatan wilayah Surabaya yaitu sepanjang Ketabang hingga Darmo. ${ }^{7}$ Jika melihat kembali sejarah Surabaya maka sejak dulu kota Surabaya adalah kota multikultural. ${ }^{8}$ Adanya urbanisasi menjadikan kota Surabaya semakin majemuk atau heterogen dengan keberagaman suku, etnis, agama dan ras.

Pembentukan beberapa kampung di Surabaya biasanya adalah kelompok minoritas yang tinggal di wilayah tersebut. Mereka membentuk zona berdasarkan pada kesamaan etnis dan ras. Selain adanya persamaan budaya, pengelompokan ini dilakukan agar mereka merasa aman dari "kaum mayoritas" dan sebagai penguatan identitas serta menunjukkan eksistensi diri di tengah kelompok mayoritas. Hal ini seperti yang dikatakan oleh Suprapto dan Huda bahwa kebutuhan untuk mengelompok dengan menciptakan kantong sosial (social enclave) ada pada kelompok minoritas sebagai upaya membentengi diri dari dominasi, kooptasi, dan hegemoni kelompok mayoritas. ${ }^{9}$ Namun dalam perkembangannya ternyata zona pemukiman di Surabaya tidak hanya berdasarkan pada ras, etnis dan ekonomi, namun juga pada ranah agama. Menjadi menarik ketika kantong sosial ini justru dibuat bagi kelompok mayoritas, yakni muslim. Islam menjadi agama mayoritas di Surabaya, sebagaimana yang ada pada tabel di bawah ini:

Table 2.

Jumlah Penduduk berdasarkan Agama yang Dianut

\begin{tabular}{lccccccc}
\hline Agama & $\mathbf{2 0 0 8}$ & $\mathbf{2 0 0 9}$ & $\mathbf{2 0 1 0}$ & $\mathbf{2 0 1 1}$ & $\mathbf{2 0 1 2}$ & $\mathbf{2 0 1 3}$ & $\mathbf{2 0 1 4}$ \\
\hline Islam & 2.191 .752 & 2.376 .576 & 2.373 .720 & 2.337 .104 & 2.576 .576 & 3.030 .012 & 2.432 .502 \\
\hline
\end{tabular}

\footnotetext{
${ }^{7}$ Eksotisme kampung-kampung Tua di Surabaya. (WomanBlitz.com, 31 Mei 2017) tersedia di https://www.womanblitz.com/eksotisme-kampung-kampung-tua-di-surabaya-part-2--899.html; Internet; diunduh pada 11 Oktober 2019

${ }^{8}$ Multikultural menekankan penghargaan dan penghormatan atas hak-hak minoritas, baik dari segi etnis, ras dan agama. Karakteristik multicultural adalah adanya keberagaman, penerimaan, memberikan hak dan kontribusi pada semua kelompok, adanya kerjasama diantara berbagai kelompok, bisa menyikapi perbedaan yang ada ((Akhyar Yusuf Lubis, Pemikiran Kritis Kontemporer, Jakarta: PT Raja Grafindo, 2015: 175-176)

${ }^{9}$ Suprapto dan Miftahul Huda, Antara Penguatan Identitas dan Komodifikasi Agama tersedia di http://repository.uinmataram.ac.id/103/1/103\%20Artikel.pdf; Internet; diunduh pada 11 Oktober 2019
}

40 Yelly Elanda 
Komodifikasi Agama Pada Perumbahan Syariah di Surabaya

\begin{tabular}{lccccccc}
\hline Katholi & 146.320 & 119.121 & 145.240 & 148.715 & 122.787 & 114.717 & 116.703 \\
k & & & & & & & \\
Kristen & 236.515 & 279.539 & 295.186 & 295.714 & 172.200 & 648.717 & 266.608 \\
\hline Hindu & 32.458 & 11.665 & 27.115 & 27.314 & 92.520 & 18.146 & 8.436 \\
Budha & 46.941 & 54.083 & 48.824 & 48.433 & 54.083 & 36.611 & 45.150 \\
\hline Konghu & - & - & - & 396 & - & 13 & 389 \\
cu & & & & & & & \\
Lainnya & - & - & - & 955 & - & 346 & 171 \\
\hline
\end{tabular}

Sumber: Badan Pusat Statistik Kota Surabaya ${ }^{10}$

Berdasarkan pada data tersebut, para pengembang melihat potensi pasar muslim sebagai penduduk mayoritas di Surabaya. Secara ekonomi kalangan muslim disebut sebagai golongan orang kaya baru atau muncul sebagai kalangan kelas menengah perkotaan. Secara budaya, gaya hidup islam berkembang pesat di kalangan kelas menengah perkotaan. Dengan berlandaskan ketiga hal itu, para developer mengembangkan konsep perumahan syariah. Namun, munculnya perumahan syariah di Surabaya semakin menambah daftar panjang segregasi spasial yang telah ada. Jika sebelumnya perumahan yang ada hanya dikategorikan berdasarkan kelas ekonomi, etnis dan ras. Hadirnya perumahan syariah ini akan menawarkan segregasi spasial baru yaitu berdasarkan pada agama. Zona pemukiman berbasis agama ini bisa mengakibatkan pembentukan dan penguatan identitas keagamaan serta akan membentuk gated community atau komunitas berpagar.

\section{Komodifikasi Agama}

Kapitalis selalu bisa membaca peluang pasar dan bisa lebih cepat beradaptasi dengan kondisi yang ada di masyarakat. Pencarian pasar tentang ruang secara geografis telah membawa kapitalis untuk menguasai lahan dan mengkomodifikasikan ruang dengan menjual wacana yang telah mereka bentuk sebelumnya. Konsep ruang tidak hanya memiliki nilai ekonomis namun juga mempunyai nilai sosiologis. Ruang adalah representasi dan simbol dari kekuasaan dan konsep ruang terus mengalami perubahan, bergerak secara dinamis sesuai dengan apa yang dikonstruksikan oleh masyarakat. Sebagaimana yang dinyatakan oleh Massey bahwa ruang merupakan hasil dari konstruksi sosial; sosial dikonstruksikan secara spasial; ruang sosial juga bersifat dinamis karena dibangun berdasarkan relasi sosial yang terus berubah; ruang juga merupakan representasi dari kekuasaan-geometri ruang yang merupakan wujud dari kekuasaan dan simbolisme. ${ }^{11}$

Mayoritas penduduk Indonesia menganut agama Islam dan sejak masa orde baru runtuh, kebangkitan identitas muslim mulai berkembang. Hal ini ditandai

10 Banyaknya Pemeluk Agama Menurut Jenisnya Hasil 2008-2014 (Surabaya: Badan Pusat Statistik Kota Surabaya, 21 januari 2016) tersedia di https://surabayakota.bps.go.id/ statictable/2016/01/21/496/banyaknya-pemeluk-agama-menujut-jenisnya-2008-2014.html; Internet; diunduh pada 11 Oktober 2019

${ }^{11}$ Chris Barker, Cultural Studies (Yogyakarta: Kreasi Wacana, 2013), 309

Yelly Elanda 41 
dengan banyaknya masyarakat yang menggunakan nilai-nilai Islam dalam kehidupan sehari-hari dengan menggunakan symbol-simbol keagamaan. Dalam bidang ekonomi, munculnya berbagai jenis bank syariah, penggunaan fashion syariah, hotel syariah, opera sabun berbasis agama, dan bahkan terdapat produk hukum berbasis syariah. Beberapa pengamat melihat kebangkitan "islamisasi” juga tampak pada budaya popular. Mereka menilai gejala ini merupakan komersialisasi kehidupan kaum muslim dan komodifikasi simbol-simbol agama. ${ }^{12}$

Islamisasi merupakan proses perubahan sosial yang melibatkan berbagai kalangan muslim yang berbeda dan tidak ada pihak yang mengendalikan proses ini. Islamisasi ini mencakup segala unsur material baik yang berupa komoditas barang dan jasa serta praktik-praktik yang dipahami dan diterima oleh masyarakat Indonesia sebagai perilaku yang mengandung nilai-nilai islami atau bersifat "islami" yang terjadi di ruang-ruang publik. ${ }^{13}$ Masyarakat Indonesia cenderung memasukkan segala unsur agama (syariah) pada produk hukum, perundang-undangan dan peraturan daerah, hal ini disebut oleh Lindsey sebagai "Syariahisation". ${ }^{4}$ Proyek syariahisasi ini juga dimanfaatkan oleh para pembisnis property atau pengembang perumahan. Dengan menggunakan konsep perumahan syariah pengembang tidak hanya menjual ruang namun lebih pada menjual simbol agama. Penggunaan simbol agama ini diharapkan dapat menarik kalangan muslim untuk membeli citra dari perumahan syariah.

\section{Bentuk-bentuk Komodifikasi Agama Pada Perumahan Syariah}

Pada dasarnya penggunaan simbol-simbol keagamaan dan penyematan kata syariah menjadi salah satu strategi yang digunakan oleh para developer untuk membangun citra dari produknya. Citra yang dibangun oleh kapitalis mengkonstruksi masyarakat secara luas atau pembeli secara khusus. Citra ini yang kemudian akan melekat sebagai identitas para penghuni perumahan syariah. Pemilihan dan hadirnya perumahan dengan konsep syariah merupakan salah satu cara yang dilakukan oleh para penghuni atau developer untuk memberikan ruang kepada para muslim untuk menunjukkan bahkan menguatkan identitasnya. Tentunya ini menjadi strategi yang berbeda dan menarik karena berbeda dengan pengembang sebelumnya yang hanya membentuk identitas penghuni secara ekonomi. Pengembang perumahan syariah ini menggunakan beberapa simbol agama, diantaranya adalah:

\section{Fasilitas Perumahan}

\footnotetext{
${ }^{12}$ Ariel Heryanto, Identitas dan Kenikmatan (Jakarta: PT Gramedia, 2015), 38

${ }^{13}$ Alina Kokoscha, "Islamizing the Market? Advertising, Products and Consumption in an Islamic Framework in Syria" dalam J. Pink (ed), Muslim Societies in the Age of Mass Consumption, (Newcastle upon Tyne: Cambridge Scholars, 2009)

${ }^{14}$ Timothy Lindsey, Human Rights and Islam in South East Asia: The Case of Indonesia, Islam und Menscchenrechte. (Switzerland: Peter Lang Publishing, 2010)
}

42 Yelly Elanda 
Salah satu yang menjadi bahan pertimbangan ketika akan membeli rumah adalah fasilitas yang disediakan oleh pihak developer. Fasilitas yang hanya dinikmati oleh penghuni perumahan merupakan bentuk privatisasi ruang. Pengembang ini mengkonstruksi pandangan bahwa penghuni perumahan boleh memanfaatkan fasilitas ruang publik yang disediakan hanya untuk komunitasnya sendiri yakni para penghuni perumahan. Di sisi lain, para kontraktor ini juga melakukan privatisasi layanan dan tanggung jawab publik yakni dengan mengembangkan sistem keamanan sendiri dan mempunyai fasilitas hiburan sendiri.

Perumahan syariah juga melakukan privatisasi ruang, privatisasi layanan publik dan tanggung jawab publik sama halnya dengan perumahan konvensional lainnya. Fasilitas keamanan 24 jam dan menggunakan one gate system adalah persamaan fasilitas yang dimiliki perumahan syariah dengan perumahan konvensional. Masalah keamanan merupakan suatu hal yang wajib disematkan pada fasilitas perumahan yang ada di Surabaya. Yang membedakan antara perumahan konvensional dengan perumahan syariah adalah fasilitas yang ada pada perumahan syariah lebih pada membentuk gaya hidup berbasis agama islam. Hal ini nampak pada semboyan yang lebih mengunggulkan "lingkungan islami". Misalnya pada kalimat "Mendambakan punya rumah dengan lingkungan aman, nyaman dan senantiasa diselimuti hangatnya Ukuwah Islamiyah?" atau pada kalimat "Beli rumah di kawasan islami" dan "Hadir dengan konsep hunian syariah, lingkungn islami dan tetangga berkualitas sehingga sangat baik untuk tumbuh kembang putra dan putri penghuni" serta menyematkan kata "lingkungan islami" pada fasilitas yang ditawarkan.

Untuk membentuk kawasan islami tersebut, para kontraktor juga menyematkan berbagai sarana peribadahan dan olahraga. Dalam hal sarana ibadah selalu lekat dengan adanya masjid/musholla, rumah tahfidz. Sedangkan sarana olahraga yang mendukung adalah tersedianya area memanah dan sarana olahraga lainnya. Untuk sarana olahraga tidak disebutkan secara spesifik seperti area memanah. Tersedianya sarana ibadah berupa mushola dan masjid mungkin juga menjadi wacana yang sama dengan perumahan konvensional. Namun yang lebih ditawarkan adalah rumah tahfidz dan area memanah sebagai sarana olahraga. Hal ini yang lebih mencolok untuk melihat perbedaan perumahan syariah dengan konvensional. Rumah tahfidz identik dengan rumah yang digunakan untuk belajar dan menghafal al quran. Di perumahan konvensional ini rumah tahfidz tidak ada karena biasanya kegiatan belajar mengaji dan seluruh kegiatan ibadah yang beragama islam dilakukan di masjid. Sedangkan di perumahan syariah kegiatan ibadah itu dipisah, tidak hanya dilakukan di masjid tapi juga di rumah tahfidz. Area memanah juga menjadi produk unggulan bagi perumahan syariah karena memanah merupakan olahraga yang disunnahkan dalam agama islam.

Fasilitas yang ada dalam perumahan syariah adalah fasilitas yang mendukung wacana tentang "lingkungan islami". Fasilitas yang disediakan oleh para pengem- 
bang akan membentuk gaya hidup para penghuninya yang identik dengan "gaya hidup islami”. Gaya hidup ini terkait dengan sikap, persepsi dan tindakan yang lazim digunakan oleh kaum muslim dengan menggabungkan antara ajaran agama dengan sesuatu hal yang bersifat materi. Kaum ini menikmati gaya hidup masyarakat perkotaan namun juga tidak bisa dilepaskan dengan ajaran agama yang mereka anut. Hal ini terbukti semua fasilitas yang disediakan oleh developer sama dengan fasilitas para perumahan konvensional pada umumnya hanya saja menambahkan "sesuatu" untuk menunjukkan kekhasannya tentang ajaran agama yakni rumah tahfidz dan area memanah.

\section{Strategi Pemasaran}

Dalam menawarkan produknya, para developer dari perumahan syariah ini melakukan strategi pemasaran yang berbeda dengan perumahan konvensional lainnya yang biasanya melakukan promosi lewat property expo yang diadakan di mall-mall. Perumahan syariah menggunakan strategi gathering yang biasanya diisi oleh para motivator, ustad dan bagian marketing yang dikonsep dengan ceramah. Tema yang disampaikan dalam acara gathering tidak langsung tertuju pada promosi perumahan syariah. Temanya biasanya berkenaan dengan "keajaiban rejeki" sehingga ada persepsi bahwa acara ini semacam kajian. Di awal akan diberikan motivasi agar para peserta tidak ragu untuk membeli rumah karena mayoritas para peserta adalah kelas pekerja dari kalangan kelas menengah masyarakat perkotaan. Para marketer menyelipkan ajaran agama pada promosi tersebut sehingga para peserta gathering tertarik membeli perumahan syariah.

Gathering biasanya dilakukan pada hari minggu saat para pekerja libur, lokasi gathering di hotel dan acara ini tidak dipungut biaya bagi peserta yang akan mengikuti. Konsep acara gathering sendiri merupakan bentuk penyesuaian gaya hidup masyarakat perkotaan kalangan kelas menengah dimana mereka akan menghabiskan waktu untuk berkumpul bersama di hari libur. Lokasi yang dipilih berupa hotel juga menunjukkan kelas para peserta dan gaya hidup dari masyarakat perkotaan. Jika biasanya kajian agama dilakukan di rumah ibadah, gathering ini justru dilakukan di hotel. Jika biasanya promosi dikemas dengan gaya hidup yang identic dengan acara yang menghibur, gathering ini justru dikonsep layaknya ceramah agama atau kajian agama. Konsep gathering dalam strategi pemasaran perumahan syariah adalah mengkolaborasi gaya hidup masyarakat perkotaan kelas menengah dengan ajaran agama dimana kalangan kelas menengah masyarakat perkotaan ini ingin mengikuti perkembangan gaya hidup masyarakat perkotaan namun tidak kehilangan iman yang dimilikinya.

\section{Penggunaan Fashion}

Dalam brosur yang dibagikan oleh perumahan syariah semuanya menggambarkan pakaian yang menunjukkan identitas muslim. Ada brosur yang menggam- 
barkan dua orang yakni laki-laki dan perempuan menggunakan baju ala Arabian. Seorang lelaki menggunakan jubah putih dengan surban diikatkan di kepalanya sedangkan seorang wanita menggunakan baju abaya lengkap dengan jilbabnya. Ada beberapa gambar juga yang menunjukkan dua orang yakni laki-laki dan perempuan nampak menggunakan baju yang casual, rapi layaknya seseorang yang akan pergi ke kantor. Namun tidak lupa, perempuan tersebut menggunakan hijab untuk menutupi rambutnya. Ada juga berupa gambar yang menunjukkan keluarga, terdiri dari ayah, ibu dan anak yang sedang mengaji, sholat dan bermain dengan temantemannya. Anak laki-laki sedang bermain dengan teman-temannya, mereka menggunakan baju setelan koko dilengkapi dengan peci. Adapula anak lelaki yang sedang belajar mengaji dengan ustadnya. Anak perempuan menggunakan baju gamis dan berhijab begitu pula dengan ibunya. Ayah menggunakan baju koko namun juga ada yang menggunakan baju casual. Di dalam gambar tersebut nampak ayah sedang sholat berjamaah dengan bapak-bapak yang lain.

Dalam brosur tersebut nampak fashion yang digunakan mencerminkan tentang identitas seorang muslim dan menunjukkan gaya hidup dari penghuni perumahan syariah. Di sisi lain dalam realitasnya, para marketingnya juga menggunakan pakaian yang juga menunjukkan statusnya sebagai seorang muslim. Jika laki-laki mereka akan berbaju koko, ada yang menggunakan peci. Sedangkan yang perempuan menggunakan gamis dan berhijab bahkan ada yang menggunakan cadar. Hal ini dilakukan agar para calon pembeli yakin bahwa perumahan yang dijual betul-betul syar'i. Pada kolom tertentu ada developer dari perumahan syariah sedang mencari tenaga marketing. Syarat yang pertama kali disebut adalah seorang muslim. Tidak hanya calon penghuni, calon pelamar kerja untuk perumahan syariah pun harus mengeliminasi agama lain untuk dapat bergabung dengan perumahan syariah.

Terdapat pula kumpulan foto para costumer yang sudah membeli unit di perumahan syariah. Dari foto-foto tersebut banyak perempuan atau ibu-ibu yang menggunakan gamis dan jilbab. Jikalau bapak-bapak banyak yang menggunakan kaos dan baju batik. Di gambar itu pula terdapat gambar mobil di setiap rumah dan di depan pintu atau portal perumahan. Gambar mobil dan fashion yang digunakan pada gambar-gambar tersebut dan juga yang digunakan oleh para marketing adalah sebagai bentuk promosi yang menggunakan simbol agama sebagai identitas sosial. Penggunaan simbol agama dan simbol mobil dalam brosur tersebut seolah ingin menunjukkan bahwa para penghuni di perumahan syariah ini adalah para muslim yang kelasnya menengah yang juga mengkuti trend masyarakat perkotaan (jika tampilannya terdapat fashion yang casual pada model laki-laki dan menunjukkan wanita karier pada model perempuan). Namun di sisi lain juga ingin menunjukkan identitas muslim yang kuat dengan menggunakan fashion yang bernuansa arab dengan jubbah dan abaya, tidak lupa penutup rambut bahkan modelnya pun 
menggunakan orang arab. Selama ini islam identik dengan arab, oleh karena itu penggunaan fashion arab juga untuk meyakinkan para pembeli. Penggunaan simbolisasi arab di Indonesia merupakan praktek komodifikasi agama yang digunakan oleh banyak pihak terutama para pengembang perumahan syariah.

\section{Sistem Pembayaran}

Perbedaan yang sangat mencolok pada perumahan syariah adalah sistem pembayarannya. Sistem pembayaran perumahan syariah yang tidak mengandung "riba" dinilai menjadi daya tarik tersendiri bagi kaum muslim. Sama halnya dengan konsep bank syariah yang konon katanya tidak ada "riba". Dalam brosur dan segala bentuk promosinya, perumahan syariah begitu mengandalkan sistem pembayarannya. Bahkan dalam sesi gathering para pembicara banyak focus pada penjelasan sistem pembayarannya. Banyak orang yang masih belum tau dengan sistem pembayaran yang tidak melibatkan pihak bank, tanpa riba, tanpa BI checking, tanpa denda, tanpa sita, tanpa asuransi dan tanpa akad bathil. Ketujuh komponen dalam sistem pembayaran ini yang diandalkan oleh pihak perumahan syariah.

Dalam brosurnya terdapat perbandingan antara perumahan syariah dengan perumahan konvensional. Perumahan syariah dinilai bebas riba, status rumah KPR milik sepenuhnya, tanpa melibatkan bank, tanpa BI checking, tanpa sistem penalty, kredit tanpa denda, tanpa sita dan akad syar'I tanpa masalah. Sedangkan perumahan konvensional dinilai 100\% riba, status rumah KPr belum jadi milik, bayar DP ke developer kekurangan ditutupi oleh bank, menggunakan BI checking, ada sistem penalty, kredit telat kenak denda, kredit macet rumah disita, akad bermasalah. Kata riba, akad syar'i merupakan konsep agama yang digunakan dalam proses jual beli termasuk dalam penjualan property. Kedua konsep ini yang dimodifikasi oleh para kapitalis untuk memperdagangkan produknya.

Perumahan syariah dijual dengan harga yang relatif lebih murah dibandingkan dengan perumahan konvensional yang lain. Para developer berdalih dengan sistem pembayaran yang demikian bisa menjual harga rumah yang lebih rumah dibandingkan dengan perumahan konvensional. Pengembang perumahan syariah beranggapan bahwa dengan sistem konvensional, perumahan konvensional banyak meraup untung. Oleh karena itu, sistem konvensional dianggap riba. Pada dasarnya perumahan syariah dengan wacana akad syar'i menjadi wacana tandingan dari perumahan konvensional yang menerapkan sistem KPR. Titik poin dari perdebatan kedua wacana tersebut adalah adanya unsur riba dalam penjualan perumahan. Para kapitalis dalam hal ini agen perumahan syariah mendayagunakan "unsur riba" untuk menyerang perumahan konvensional dan untuk menjual perumahan yang berbasis syariah. 


\section{Dampak Komodifikasi Agama Pada Perumahan Syariah}

Bagi para kapitalis, menggunakan simbol agama dalam berbagai penjualan produk adalah salah satu cara untuk meraup keuntungan. Para kapitalis mungkin juga tidak pernah terpikirkan dampak dari adanya wacana "agama" yang sudah mereka mainkan dalam iklan atau promosi bagi masyarakat. Pada kenyataannya komodifikasi agama ini tidak hanya berdanpak pada penjualan produk namun juga berdampak secara sosial. Citra yang dibentuk oleh kapitalis untuk memasarkan produknya sangat melekat bahkan berpengaruh terhadap pandangan masyarakat, termasuk dalam hal perumahan syariah. Adanya perumahan syariah ini berdampak langsung pada pola interaksi, hubungan sosial yang ada pada masyarakat. Berbeda halnya dengan kemunculan bank syariah dan hotel syariah. Perumahan syariah tidak hanya sekedar membeli bangunan dan lingkungan dengan menggunakan sistem pembayaran syariah namun juga pola gaya hidup yang berkenaan dengan nilai dan norma yang diterapkan pada perumahan syariah. Secara sosiologis, setidaknya ada dua dampak yang akan ditimbulkan dari adanya komodfiikasi agama pada perumahan syariah:

\section{Pembentukan dan Penguatan Identitas Sosial}

Identitas sosial merupakan hasil konstruksi sosial dan tidak bisa terlepas dari budaya yang berlaku. Hal ini senada dengan apa yang dikatakan oleh Beger dan Luckmann bahwa identitas dibentuk melalui proses sosial. ${ }^{15}$ Sama halnya dengan Barker identitas sepenuhnya merupakan konstruksi sosial dan tidak mungkin eksis di luar representasi kultural dan akulturalisasi. ${ }^{16}$ Identitas sosial bersifat dinamis tergantung pada konteks ruang dan waktu. Sebagaimana yang dinyatakan oleh Damsar, identitas dapat dipahami sebagai suatu pertanyaan tentang siapa aku, terkait dengan ruang dan waktu sosial. ${ }^{17}$ Sama halnya dengan apa yang diungkapkan oleh Barker bahwa identitas adalah konstruksi diskursif yang berubah maknanya menurut ruang, waktu dan pemakaian. ${ }^{18}$ Melalui identitas, kita bisa melihat persamaan dan perbedaan tentang aspek personal dan sosial karena setiap orang memiliki identitas diri dan identitas sosial.

Identitas merupakan representasi dari kultural dimana kita dibesarkan. Hal ini juga dikatakan oleh Hall (1992b:75) bahwa subjek dipengaruhi oleh "orang yang berpengaruh" (significant others), yang menjadi perantara subjek dengan nilai, makna dan symbol kebudayaan dimana dia tinggal. ${ }^{19}$ Tempat tinggal adalah salah satu simbol yang menggambarkan identitas sebab identitas dibentuk dimana

\footnotetext{
15 Peter L Berger dan Thomas Luckmann, Tafsir Sosial atas Kenyataan, Risalah tentang Sosiologi Pengetahuan (Jakarta: LP3ES, 1990)

${ }^{16}$ Chris Barker, Cultural Studies (Yogyakarta: Kreasi Wacana, 2013), 174

${ }^{17}$ Damsar, Sosiologi Konsumsi. (Jakarta: Universitas Terbuka, 2009)

${ }^{18}$ Chris Barker, Cultural Studies (Yogyakarta: Kreasi Wacana, 2013), 175

${ }^{19}$ Chris Barker, Cultural Studies (Yogyakarta: Kreasi Wacana, 2013), 177
} 
seseorang hidup atau tinggal. Berkenaan dengan ruang dan tempat tinggal yang merupakan simbol penguasaan atau penaklukan atas suatu ruang atau daerah. Terbentuknya kawasan atau zona di perkotaan juga mengindikasikan persaingan kelompok sosial untuk menguasai ruang baik secara simbolis maupun material. Zukin (1996b:43) mempertanyakan tentang kepemilikan kota, menyangkut siapa saja yang memiliki hak untuk mendiami adalah gambaran sebuah kota. Disebut dengan strategi geografis ketika kelompok sosial yang berbeda bertarung untuk mendapatkan akses terhadap pusat kota dan representasi simbol pusat kota. Ada dua hal yang penting dalam pertanyaan kota punya siapa? Pertama, representasi sebuah kota menunjuk pada kelompok sosial yang menandai inklusi dan ekslusi. Kedua, ruang dibentuk melalui investasi modal dengan makna kultural, dengan menyatukan legibilitas dan identitas. ${ }^{20}$

Di Surabaya sendiri bukan hal yang baru jika banyak perumahan, banyaknya jumlah penduduk membuat para developer untuk terus membangun perumahan. Terlebih perumahan dengan sistem keamanan yang terjamin adalah fasilitas yang wajib ada di perumahan. Pada zona-zona tertentu di daerah Surabaya sudah terkenal dengan sebutan kawasan elite, rumah dengan bangunan yang besar dan bertingkat, pagar yang tinggi dan tertutup serta halaman yang luas. Perumahan yang demikian berada di kawasan yang strategis dekat dengan pusat kota karena harganya pun pasti fantastis. Semakin lama lahan yang berada di kota Surabaya semakin mahal, hal ini dikarenakan semakin sempitnya lahan yang tersedia untuk perumahan. Oleh karena itu para developer banyak yang mengembangkan perumahan di pinggiran kota Surabaya yang berbatasan dengan Sidoarjo dan Gresik. Mengapa dipilih daerah ini? Pertama, Sidoarjo dan Gresik menjadi kota yang berkembang seiring dengan perkembangan kota Surabaya. Kedua, banyak para pekerja Surabaya yang berasal dari Gresik dan Sidoarjo. Ketiga, lahan di Gresik dan Sidoarjo relatif lebih murah dibandingkan dengan Surabaya karena ketersediaan lahan kosong di kedua kota tersebut lebih banyak.

Melihat peluang tersebut, developer berinisiatif untuk mendirikan perumahan yang harganya relatif lebih murah dan terjangkau oleh para pekerja atau kalangan kelas menengah. Dengan harga berkisar 400-600 juta, uang muka rendah dan bisa kredit atau dikenal KPR perumahan ini menjadi laris manis namun di sisi lain persaingan diantara para developer tidak bisa dihindari. Ada beberapa developer yang membuat strategi dengan menggunakan kata syariah pada perumahan yang dikembangkannya. Sama halnya dengan bank syariah yang menggunakan isu agama sebagai promosinya. Harga yang ditawarkan pada perumahan syariah pun lebih murah dibandingkan dengan perumahan lainnya. Fasilitas yang ditawarkan pun sangat mendukung bagi kegiatan agama serta isu-isu terkait dengan pendidikan anak untuk

${ }^{20}$ Chris Barker, Cultural Studies (Yogyakarta: Kreasi Wacana, 2013), 319-320

48 Yelly Elanda 
mendapatkan lingkungan yang baik juga turut jadi bahan promosi.

Lalu mengapa isu agama yang digunakan? Hal ini tidak bisa terlepas dari pertama, jumlah pemeluk agama islam yang lebih dominan. Kedua, lingkungan Surabaya, Gresik dan Sidoarjo masih memegang ajaran-ajaran Islam yang kuat. Ketiga, munculnya kalangan kelas menengah islam dimana mereka juga ingin menunjukkan eksistensinya dengan gaya hidup yang berbeda dengan masyarakat kota lainnya. Perbedaanya terletak pada penonjolan simbol-simbol agama yang mereka gunakan dalam kehidupan sehari-hari. Menurut Heryanto, sosok baru muslim ini mayoritas masih muda, berasal dari golongan kelas menengah (pendidikan, kecanggihan budaya, kehormatan diri, dan gengsi) sama seperti golongan kelas menengah lainnya, hanya saja mereka lebih membanggakan ketakwaan beragama mereka. Yang terpenting adalah ketaatan beragama yang terpelihara dengan baik memungkinkan mereka dengan bangga mempertahankan perasaan bahwa mereka berbeda dengan yang lain. ${ }^{21}$

Perasaan berbeda dengan yang lain inilah yang menunjukkan status mereka menjadi berbeda dengan yang lain. Perumahan syariah dengan perumahan konvensional tidak hanya berbeda secara fisik bangunan dan sistem pembayarannya saja tapi akan membedakan identitas penghuninya. Penghuni perumahan syariah ini akan memiliki perasaan yang berbeda dengan penghuni perumahan konvensional dan masyarakat pun akan memberikan penilaian yang berbeda antara penghuni perumahan konvensional dengan perumahan syariah. Unsur agama akan lebih melekat pada perumahan syariah. Rasa bangga mengenai ketaatan agama penghuni syariah lebih kental dibandingkan dengan penghuni perumahan konvensional meskipun mereka sama-sama menganut agama islam. Hal ini dikarenakan kuatnya penggunaan simbol-simbol agama pada perumahan syariah.

Perumahan syariah ini bisa dikatakan sebagai wadah eksistensi para kaum kelas menengah muslim yang ingin menggunakan uangnya untuk menikmati selera kebudayaan yang sama dengan masyarakat perkotaannya lainnya. Namun mereka tidak ingin mengorbankan keimanan yang dimilikinya. Perumahan syariah ini pada akhirnya akan menguatkan identitas sosial para penghuninya sebagai muslim kelas menengah masyarakat kota. Perumahan syariah ini mengkolaborasikan gaya hidup masyarakat kota yang identik dengan budaya konsumen kapitalisme modern dan religiusitas penganut agama yang tampak dari integritas moralnya.

\section{Terbentuknya Masyarakat Berpagar atau Gated Community}

Masyarakat berpagar di Amerika dan Negara lain merupakan salah satu sumber terjadinya fragmentasi kota. Komunitas berpagar telah menciptakan batas-batas ruang sosial berdasarkan pada batas fisik. Pagar tidak hanya mendefinisikan

${ }^{21}$ Ariel Heryanto, Identitas dan Kenikmatan (Jakarta: PT Gramedia, 2015), 54 
kepemilikan pribadi namun juga sebagai simbol pengelompokan masyarakat tertentu. Namun di Indonesia komuitas berpagar ini digunakan untuk membatasi diri dari masalah keamanan dan sosial. Komunitas berpagar dihuni bukan hanya golongan kelas atas namun juga kalangan menengah pekerja yang memiliki kecenderungan gaya hidup dan konsumsi mewah. ${ }^{22}$ Di Surabaya, hampir semua perumahan menjual sistem keamanan, karena perumahan Surabaya terbentuk adanya ketakutan dari tindakan kriminalitas. Namun dalam perkembangannya perumahan ini justru menjadi kelompok sosial yang ekslusif.

Ekslusivisme ditandai dengan bentuk relasi yang tertutup, memisahkan diri dari lingkungan sekitar, mempertegas batas antara warga perumahan dengan warga lain, membentuk identitas baru biasanya berkenaan dengan status sosial ekonomi, gaya hidup dan lain sebagainya. Dengan demikian maka akan berimplikasi pada segregasi spasial, segregasi sosial yang berujung pada konflik. Sebagaimana yang terjadi pada bulan april tahun 2008, konflik terjadi antara warga dengan perumahan darmo satelit yang merupakan salah satu perumahan elit di Surabaya. Warga yang marah memblokade gerbang masuk dengan cara mengelas portal besi di perumahan mewah tersebut. ${ }^{23}$

Konflik yang terjadi di tahun 2008 itu tidak berpengaruh pada perkembangan pembangunan perumahan di Surabaya. Sistem perumahan di Surabaya justru semakin banyak diminati. Hal ini tidak terlepas dari adanya wacana pembentukan citra perumahan yang digagas oleh para pengembang. Secara tidak langsung publik akan menyematkan identitas sesuai dengan citra yang telah menggaung. Faktor keamanan, label yang disematkan antara "kampung" dan perumahan seolah-olah membedakan antara tradisional dengan yang modern, gaya hidup yang dilengkapi dengan fasilitas perumahan menjadi kunci para pengembang untuk membangun wacana.

Dalam perkembangannya, pola pemukiman atau perumahan di daerah Surabaya tidak hanya membentuk segregasi sosial secara ekonomi melainkan juga secara agama. Munculnya perumahan berbasis syariah akhir-akhir ini menunjukkan bahwa agama sudah menjadi gaya hidup bagi masyarakat di wilayah perkotaan. Masyarakat kota tidak hanya menginginkan keamanan lingkungan saja namun juga keamanan dalam melakukan ibadah, gaya hidup tidak lagi bersandar pada ekonomi saja melainkan juga pada nilai agama. Gaya hidup syariah ini bisa dilihat dari fasilitas yang ada dalam perumahan. Fasilitas ini yang membedakan perumahan syariah

${ }^{22}$ Derajad S.Widhyharto. Komunitas Berpagar: Antara Inovasi dan Ketegangan Sosial (Studi Kasus Komunitas Berpagar di Yogyakarta) (Yogyakarta: Jurnal Ilmu Sosial dan Ilmu Politik, Vol 13 No 2: 204-230, November 2009) tersedia di https://jurnal.ugm.ac.id/jsp/article/ view/10962; Internet diunduh pada 10 Oktober 2019

${ }^{23}$ Ridwan Kamil, Arogansi "Gated Community" di Kota Kita tersedia pada https:// ridwankamil.wordpress.com/2008/10/02/arogansi-gated-community-di-kota-kita/; Internet diunduh tanggal 16 Oktober 2019

50 Yelly Elanda 
dengan perumahan yang konvensional dan penghuni dari perumahan ini juga berbeda dengan perumahan konvensional lainnya. Penghuni perumahan syariah mengarah pada agama tertentu yakni islam.

Perumahan syariah dengan sistem gated community ini tentunya akan melahirkan ekslusi sosial bahkan lebih ekslusif lagi karena tidak hanya berdasarkan pada ekonomi namun juga pada agama. Ekslusi sosial adalah istilah yang digunakan pada komunitas yang menjauhkan diri dari komunitas yang lain atau masyarakat. ${ }^{24}$ Terdapat sekat antara komunitas yang tinggal di perumahan syariah dengan masyarakat di sekitarnya dengan adanya sistem keamanan dan batasan tembok perumahan. Terlebih perumahan syariah ini lebih mengekslusifkan diri dengan ada standar ketentuan penghuni berdasarkan pada agama yang artinya perumahan syariah ini akan membentuk komunitas dengan agama tertentu. Lalu apa yang akan terjadi jika sistem gated community ini juga ada pada perumahan syariah?

Pertama, terjadi segregasi spasial. Sistem perumahan tentunya akan berbeda dengan perumahan "kampung". Perumahan dengan lingkungan yang lebih teratur, dengan pagar pembatas yang membedakan antara komunitas di luar dan di dalam pagar. Dengan adanya pagar pembatas ini maka akan memfilter siapa saja yang belum masuk atau mengakses kawasan perumahan ini. Tidak hanya itu, untuk menjadi penghuni perumahan syariah maka harus memiliki agama yang sama yakni islam. Perumahan syariah ini seolah mengkavling bahwa para penghuninya atau daerah tersebut adalah kawasan islami.

Kedua, terjadi segregasi sosial, pagar yang membatasi perumahan syariah dengan masyarakat yang ada di lingkungan sekitarnya juga akan membatasi interaksi sosial. Tidak hanya privatisasi lahan oleh penghuni perumahan dengan berbagai fasilitas umum yang hanya boleh dinikmati oleh para penghuninya namun juga berdampak secara sosial. Pagar tembok perumahan itu sebagai petanda bahwa penghuni perumahan syariah ini tidak hanya kalangan kelas menengah saja namun juga harus beragama islam. Untuk menjadi penghuni di perumahan syariah ini harus memiliki dua tiket yakni mampu secara ekonomi juga harus beragama islam. Pengeliminasian ini bisa berujung pada konflik secara horizontal, konflik agama karena akan memfragmentasi komunitas perumahan berdasarkan pada keyakinan.

Ketiga, terjadi perbedaan ikatan sosial atau solidaritas sosial. Penghuni perumahan syariah tidak ada unsur historisitas dengan lokasi tempat tinggalnya. Berbeda dengan masyarakat yang sudah lama tinggal di daerah sekitar perumahan atau masyarakat kampung. Masyarakat desa ini akan lebih kuat ikatan emosionalnya terhadap daerah tersebut dikarenakan ada sejarah dengan lingkungannya. Penghuni perumahan syariah ini hanya sebagai pembeli dari perumahan yang tinggal menempati saja, tidak terlibat dalam proses pembentukan lingkungan. Oleh karena itu

\footnotetext{
${ }^{24}$ Sunyoto Usman, Esai-Esai Sosiologi Perubahan Sosial (Yogyakarta: Pustaka Pelajar, 2015)
} 
mereka tidak punya tanggung jawab secara sosial jika terjadi sesuatu di lingkungan desanya atau di luar perumahannya. Di sisi lain ikatan sosial di dalam in group perumahan akan lebih kuat karena adanya persamaan agama dan lokasi tempat tinggal.

\section{Kesimpulan}

Munculnya perumahan syariah merupakan konsep tandingan dari perumahan konvensional yang selama ini telah ada. Perumahan syariah menggunakan simbolsimbol agama untuk menyerang perumahan konvensional. Hal ini tidak luput dari konteks sosial ekonomi dan budaya masyarakat perkotaan dimana jumlah penganut kaum muslim semakin banyak dan tingkat perekonomiannya beranjak naik menjadi kaum kelas menengah perkotaan. Kondisi yang demikian membuat agen property untuk menerapkan perumahan berbasis syariah. Pada dasarnya konsep perumahan syariah ini mengawinkan konsep perumahan konvensional yang telah ada sebelumnya dengan konsep agama sehingga membentuk suatu gaya hidup dan identitas baru di kalangan masyarakat perkotaan. Di sisi lain konsep perumahan syariah ini juga semakin menambah deretan masalah segregasi spasial dan sosial dengan sistem gated community.

Penyediaan segala macam fasilitas dalam perumahan syariah, penggunaan fashion pada model yang ada pada brosur dan pihak marketing, sistem pembayaran berbasis akad syar'i dan strategi pemasaran dengan konsep gathering adalah berbagai cara yang digunakan pengembang dengan menggunakan simbol-simbol keagamaan untuk menjual produknya. Pemanfaatan simbol-simbol keagamaan pada penjualan perumahan syariah dinilai sebagai bentuk komodifikasi agama. Hal ini tentunya akan membentuk identitas pemilik rumah dan image perumahan syariah bahwa perumahan syariah diperuntukkan bagi kaum muslim golongan kelas menengah masyarakat perkotaan. Kalangan ini adalah kaum yang menikmati gaya hidup masyarakat perkotaan namun tidak bisa dilepaskan dari keimanan yang dimilikinya. Perumahan syariah juga memiliki sistem gated community yang akan menimbulkan segregasi sosial dan spasial tidak hanya berdasarkan pada ekonomi saja namun juga pada agama, ikatan sosial sesama penghuni perumahan bukan hanya berdasar pada lokasi tempat tinggal saja melainkan juga ada kesamaan agama. Pada akhirnya perumahan syariah tidak hanya mengekslusikan diri secara vertikal (ekonomi) namun juga secara horizontal (agama).

\section{Daftar Pustaka}

Banyaknya Pemeluk Agama Menurut Jenisnya Hasil 2008-2014. Surabaya: Badan Pusat Statistik

Banyaknya Penduduk Datang yang Dilaporkan Hasil Registrasi 2009-2014. Surabaya: Badan Pusat Statistik Kota Surabaya, 17 April 2018) tersedia di 
Barker, Chris. Cultural Studies. Yogyakarta: Kreasi Wacana, 2013

Berger, Peter L.dan Luckmann, Thomas.Tafsir Sosial atas Kenyataan, Risalah tentang Sosiologi

Consumption). Newcastle upon Tyne: Cambridge Scholars, 2009

Cultural Anthropology, 2009

Damsar\&Indiriyani. Pengantar Sosiologi Perkotaan.Jakarta: Kencana, 2017

Eksotisme kampung-kampung Tua di Surabaya. WomanBlitz.com, 31 Mei 2017 tersedia di https://www.womanblitz.com/eksotisme-kampung-kampungtua-di-surabaya-part-2-899.html; Internet; diunduh pada 11 Oktober 2019

Framework in Syria" dalam (J. Pink (ed), Muslim Societies in the Age of Mass

Heryanto, Ariel. Identitas dan Kenikmatan. Jakarta: PT Gramedia, 2015

http://repository.uinmataram.ac.id/103/1/103\%20Artikel.pdf; Internet; diunduh pada 11 Oktober 2019

https://ridwankamil.wordpress.com/2008/10/02/arogansi-gated-community-di-kotakita/; Internet diunduh tanggal 16 Oktober 2019 https://surabayakota.bps.go.id/statictable/2015/01/09/329/banyaknyapenduduk-datang yang-dilaporkan-per-kecamatan-hasil-registrasi-2009--2014.html; Internet; diunduh pada 11 Oktober 2019

Kasus Komunitas Berpagar di Yogyakarta) (Yogyakarta: Jurnal Ilmu Sosial dan Ilmu

Kokoscha, Alina. "Islamizing the Market? Advertising, Products and Consumption in an Islamic

Kota Surabaya, 21 januari 2016. tersedia di https://surabayakota.bps.go.id/ statictable/2016/01/21/496/banyaknya-pemeluk-agama menujut-jenisnya2008-2014.html; Internet; diunduh pada 11 Oktober 2019

Lindsey, Timothy.Human Rights and Islam in South East Asia: The Case of Indonesia, Islam

Lubis, Akhyar Yusuf. Pemikiran Kritis Kontemporer. Jakarta: PT Raja Grafindo, 2015

Pengetahuan.Jakarta: LP3ES, 1990

Politik, Vol 13 No 2: 204-230, November 2009) tersedia di https://jurnal. ugm.ac.id/jsp/article/view/10962; Internet diunduh pada 10 Oktober 2019

Ridwan Kamil, Arogansi "Gated Community” di Kota Kita tersedia pada

Rudnyckj, Daromir. Spiritual Economies: Islam and Neoliberalism in Contemporary Indonesia.

Suprapto dan Huda, Miftahul. Antara Penguatan Identitas dan Komodifikasi Agama tersedia di

und Menscchenrechte. Switzerland: Peter Lang Publishing, 2010

Usman, Sunyoto. Esai-Esai Sosiologi Perubahan Sosial. Yogyakarta: Pustaka Pelajar, 2015 
Al-Hikmah. Vol, 17 No. 2 Oktober 2019

Widhyharto, Derajad S. Komunitas Berpagar: Antara Inovasi dan Ketegangan Sosial (Studi

54 Yelly Elanda 